\title{
Modul Berbasis Reflektif Untuk Meningkatkan Kemampuan Matematis Mahasiswa pada Perkuliahan Kalkulus I
}

\author{
Marwia Tamrin Bakar ${ }^{1}$, Ida Kurnia Waliyanti ${ }^{1}$, Soleman Saidi ${ }^{1}$ \\ ${ }^{1}$ Program Studi Pendidikan Matematika Universitas Khairun, Ternate, Indonesia; \\ tmarwia@gmail.com
}

Dikirim: 2 Juli 2018 ; Diterima: 25 September 2018; Dipublikasikan: 30 September 2018 Cara sitasi: Bakar, M. T., Waliyanti, I. K., dan Saidi, S. 2018. Modul Berbasis Reflektif Untuk Meningkatkan Kemampuan Matematis Mahasiswa Pada Perkuliahan Kalkulus. JNPM (Jurnal Nasional Pendidikan Matematika) Vol. 2(2), Hal.296-303.

\begin{abstract}
Abstrak. Penelitian ini adalah penelitian pengembangan berdasarkan model 4-D. bahan ajar yang dikembangkan adalah sebuah modul berbasis reflektif yang valid, praktis dan efektif pada matakuliah kalkulus I, yang dapat membantu mahasiswa belajar secara mandiri dengan memanfaatkan pengalaman/pengetahuan mereka sebelumnya untuk meningkatkan kemampuan matematis mahasiswa. Penelitian ini meliputi dua tahapan dari desain 4-D, yakni tahap define dan design, Hasil pada tahap define diperoleh bahwa materi yang berikan sudah sesuai silabus. Analisis pada buku teks yang digunakan yakni buku Kalkulus dan Ilmu Ukur Analitik Leithold edisi kelima jilid 1, Kalkulus karangan Edwin J. Purchell dan Dale Van Verberg edisi kesembilan, diperoleh hasil bahwa penyajian materi dan bahasa yang digunakan kurang sesuai dengan kemampuan sebagian besar mahasiswa pada prodi Pendidikan Matematika Universitas Khairun. Hasil wawancara dengan teman sejawat diperoleh bahwa mahasiswa masih memiliki kendala pada kemampuan dasar matematika, misalnya pada sifat-sifat aljabar dan sifat urutan. Hasil pada tahap design adalah telah diracang modul berdasarkan desain modul berbasis reflektif.
\end{abstract}

Kata Kunci: Berbasis reflektif, Kalkulus, Modul, Pendidikan Matematka

\begin{abstract}
This research is a development research based on the 4-D model. instructional material developed is a valid, practical and effective reflective based module on calculus I courses, which can help students learn independently by using previous experience to improve students' mathematical abilities. This study covers two dimensions of 4-D design, namely the stage of determining and designing, the results at the final stage determine the material that is in accordance with the syllabus. Analysis of books which are books of Calculus and Leithold Analytical Measuring Sciences from volume 1, ninth edition of Edwin J. Purchell and Dale Van Verberg Calculus, get results that present material and language that are not in accordance with the ability of most students in
\end{abstract}


the Mathematics Education Study Program at Khairun University . The results of interviews with colleagues found that students still have a basis for basic mathematical abilities, for example in algebraic properties and sequence properties. The results at the design stage are designed as modules based on reflective module design.

Keywords: Reflective based, Calculus, Module, Mathematics Education

\section{Pendahuluan}

Kalkulus I memiliki konsep yang baku (Warsoma dan Wono:2007) dan tidak mengalami perubahan. Kalkulus I dapat direvisi pada cara penyajian materi, dan bahan ajar. Secara teori konsep kalkulus sudah diperkenalkan pada jenjang pendidikan sebelumnya yakni Sekolah Menengah Atas (SMA), sehingga pemahaman mahasiswa tentang konsep kalkulus haruslah tinggi. Kenyataannya bahwa kemampuan mahasiswa pada mata kuliah kalkulus masih jauh dari yang diharapkan, sebagaimana sejalan dengan hasil penelitian Hartono dan Noto (2017) dan data yang diperoleh untuk 97 mahasiswa Program Studi Pendidikan Matematika tahun pelajaran 2014/2015 yang disajikan pada tabel 1. berikut:

Tabel 1. Kemampuan Matematis Mahasiswa Tahun Pelajaran 2014/2015 pada Mata kuliah Kalkulus I

\begin{tabular}{ccc}
\hline Nilai & Jumlah & $\begin{array}{c}\text { Persentase } \\
(\%)\end{array}$ \\
\hline A & 9 & 9.28 \\
AB & 10 & 10,31 \\
B & 13 & 13,40 \\
BC & 15 & 15,46 \\
C & 35 & 36,08 \\
D & 7 & 7,22 \\
E & 8 & 8,25 \\
Jumlah & 97 & 100 \\
Mahasiswa & & \\
\hline
\end{tabular}

Sumber: Program Studi Pendidikan Matematika

Data pada tabel 1 terlihat bahwa mahasiswa yang memperoleh skor kurang dari 65 (kategori BC, C, D dan E) yakni sebanyak 65 orang mahasiswa dengan persentasi $64,01 \%$, sedangkan mahasiswa yang memperoleh skor di atas 65 (kategori A, AB dan B) sebanyak 32 orang dengan persentasi 32,99\%. Artinya bahwa kemampuan mahasiswa pada perkuliahan kalkukus I masih lemah, karena kebanyakan mahasiswa memperoleh nilai C (cukup). Hal ini mengindikasikan bahwa ada sebuah kondisi yang dianggap /dipandang keliru atau tidak cocok dalam proses perkuliahan pada mata kuliah kalkulus 
I. Diantara kemungkinan ketimpangan tersebut secara garis besar menurut Suryadi (2013) disebabkan oleh tiga faktor, yaitu faktor dosen, faktor bahan ajar dan faktor mahasiswa, dipandang sebagai sebuah kesatuan yang bersifat saling terhubung anatar satu dengan yang lain. Faktor dosen terkait cara pandang dosen tentang materi, cara mengimplementasikan materi yang dipahami dalam proses pembelajaran (metode, strategi yang digunakan).

Berdasarkan pengamatan peneliti metode mengajar yang umun digunakan pada perkuliahan kalkulus I adalah metode ceramah dimana dosen berperan aktif sebagai penyampai informasi dan mahasiswa sebagai pendengar artinya bahwa pembelajaran berfokus pada dosen dan mahasiswa sebagai pihak penerima informasi, dianggap kurang cocok dengan karakteristik matakuliah serta menghilangkan kemandirian mahasiswa dalam belajar. Hal ini dapat mengakibatkan rendahnya motivasi mahasiswa untuk belajar serta buku teks yang dalam pembelajaran kurang komunikatif dalam pandangan mahasiswa. Hal ini menjadi alasan peneliti untuk mengembangkan modul berbasis reflektif yang valid, praktis dan efektif untuk meningkatkan kemampuan matematis mahasiswa pada matakuliah kalkulus di Program Studi (prodi) Pendidikan Matematika Universitas Khairun Ternate.

\section{Metode Penelitian}

Penelitian yang dilakukan ini adalah penelitian pengembangan (Research and development/RED). Penelitian dan pengembangan menurut Sujadi (2003) merupakan suatu proses atau langkah untuk mengembangkan suatu produk yang baru atau menyempurnakan produk yang sudah ada, dan dapat dipertanggungjawabkan. Penelitian pengembangan ini menggunakan rancangan 4-D desain Thiagarajan, Semmel, dan Semmel (Noto, 2014). Rancangan 4-D ini meliputi: pendefinisian (define), perancangan (design), pengembangan (develop), dan penyebaran (desseminate). Artikel ini melaporkan penelitian pada tahap define dan design

Tahap Pendefinisian (define)

Kegiatan pada tahapan ini dilakukan untuk melihat kondisi yang berhubungan dengan proses perkuliahan Kalkulus I di Proi Pendidikan Matematika Universitas Khairun, kemudian menganalisis. Kegiatan tersebut meliputi: 
a. Menganalisis silabus. Bertujuan untuk mengetahui apakah materi yang diajarkan sudah sesuai dengan standar kompetensi dan kompetensi dasar mata kuliah.

b. Menganalisis buku-buku teks Kalkulus I, bertujuan untuk melihat kesesuaian isi buku dengan standar kompetensi dan kompetensi dasar yang harus dicapai mahasiswa

c. Mereviuw literatur yang terkait dengan pengembangan modul. Tujuan dari tahap ini yaitu untuk melihat rujukan mengenai modul dan pembelajaran berbasis reflektif.

d. Wawancara dengan teman sejawat dan mahasiswa. Tujuannya untuk mengetahui masalah/hambatan apa saja yang dihadapi dalam proses perkuliahan Kalkulus I

\section{Tahap Perancangan (design)}

Pada tahap perancangan, modul dibuat menjadi empat bagian yang dapat dipergunakan untuk satu semester, bagian-bagiannya yaitu: modul 1 tentang Sistem bilangan, pertaksamaan dan Koordinat Kartesius; modul 2 tentang fungsi, limit dan kekontinuan; modul 3 tentang turunan, dan modul 4 tentang penggunaan turunan.

Setiap modul berisi standar kompetensi, uraian materi, contoh soal diserta reflektif ,latihan dengan reflektif, latihan mandiri, umpan balik, tindak lanjut, dan kunci jawaban. Setiap modul memiliki beberapa kegiatan belajar yang dengan berpedoman pada silabus matakuliah kalkulus.

Pedoman wawancara, lembar observasi dan literatur pendukung adalah instrumen yang digunakan untuk mengetahui metode mengajar dan bahan ajar yang dugunakan, serta kendala yang dialami dosen pengampu saat mengajar matakuliah kalkulus. Instrumen ini digunakan karena, artikel ini baru melaporkan pada aspek desain, sedangkan menguji validitas, praktilitas dan efektivitas akan dilakukan pada tahap development

\section{Hasil dan Pembahasan}

\section{Tahap Define}

Pada tahap ini dilakukan analisis silabus mata kuliah kalkulus I. Analisis ini dilakukan untuk melihat kesesuaian materi dengan kompetensi yang harus dimiliki oleh mahasiswa. Hasil analisis diperoleh bahwa terdapat empat materi utama yakni pendahuluan, limit dan fungsi, turunan dan aplikasi turunan yang terdapat pada silabus kalkulus I. Urutan materi juga 
disesuaikan dengan struktur pada matakuliah kalkulus dan prasyarat kalkulus. Hal ini menandakan bahwa penyusunan silabus telah memenuhi khirarki keterurutan materi dan disesuaikan dengan standar kompetensi dan kompetensi dasar yang harus dimiliki oleh mahasiswa.

Langkah selanjutnya adalah menganalisis buku teks dan buku rujukan Kalkulus I yang digunakan dosen. Buku teks yang dianalisis adalah adalah buku kalkulus karangan Varbeg Purcell Rigdom, dan Edwin J. Purchell dan Dale Van Verberg edisi kesembilan serta buku kalkulus karangan Leithold. Hasil analisi diperoleh bahwa kandungan buku telah memenuhi standar kompetensi yang harus dimiliki mahasiswa pada perkuliahan kalkulus I, namun penyajian materi dan bahasa yang digunakan kurang sesuai dengan tingkat kemampuan sebagian besar mahasiswa program studi pendidikan matematika UniversitasKhairun Ternate.

Selanjutnya peneliti melakukan konfirmasi data hasil observasi yang diperoleh terkait proses perkuliahan kalkulus I, dengan melakukan diskusi dengan teman sejawat yang mengampu matakuliah kalkulus I. Hasil diskusi diperoleh bahwa perkuliahan berfokus pada dosen dan mahasiswa bersifat pasif. Perkuliahan cenderung menggunakan metode ceramah pada proses perkuliahan kalkulus I dan mahasiswa memiliki kendala pada kemampuan dasar matematika.. Informasi ini menguatkan data observasi yang peneliti peroleh dilapangan. Metode ceramah bukanlah suatu metode yang seluruhnya salah, namun dianggap kurang tepat pada matakuliah kalkulus I, karena dianggap mengurangi sikap kritis dan mandiri mahasiswa dalam belajar. Karenanya diperlukan suatu metode yang mampu memandirikan mahasiswa dan mengurangi ketergantungan kepada dosen dalam belajar kalkulus.

Analisis literatur terkait modul berbasis reflektif dilakukan bersamaan dengan analisis buku teks. Literatur yang dijadikan panduan adalah buku teknik penyusunan modul dan strategi pembelajaran inovatif kontemporer. Fokus analisisnya pada kemampuan pra syarat dari setiap materi dalam modul berbasis refleksi. Hasil tahap difine di rangkum dalam bentuk bagan sebagaimana terlihat pada Bagan 1 berikut: 


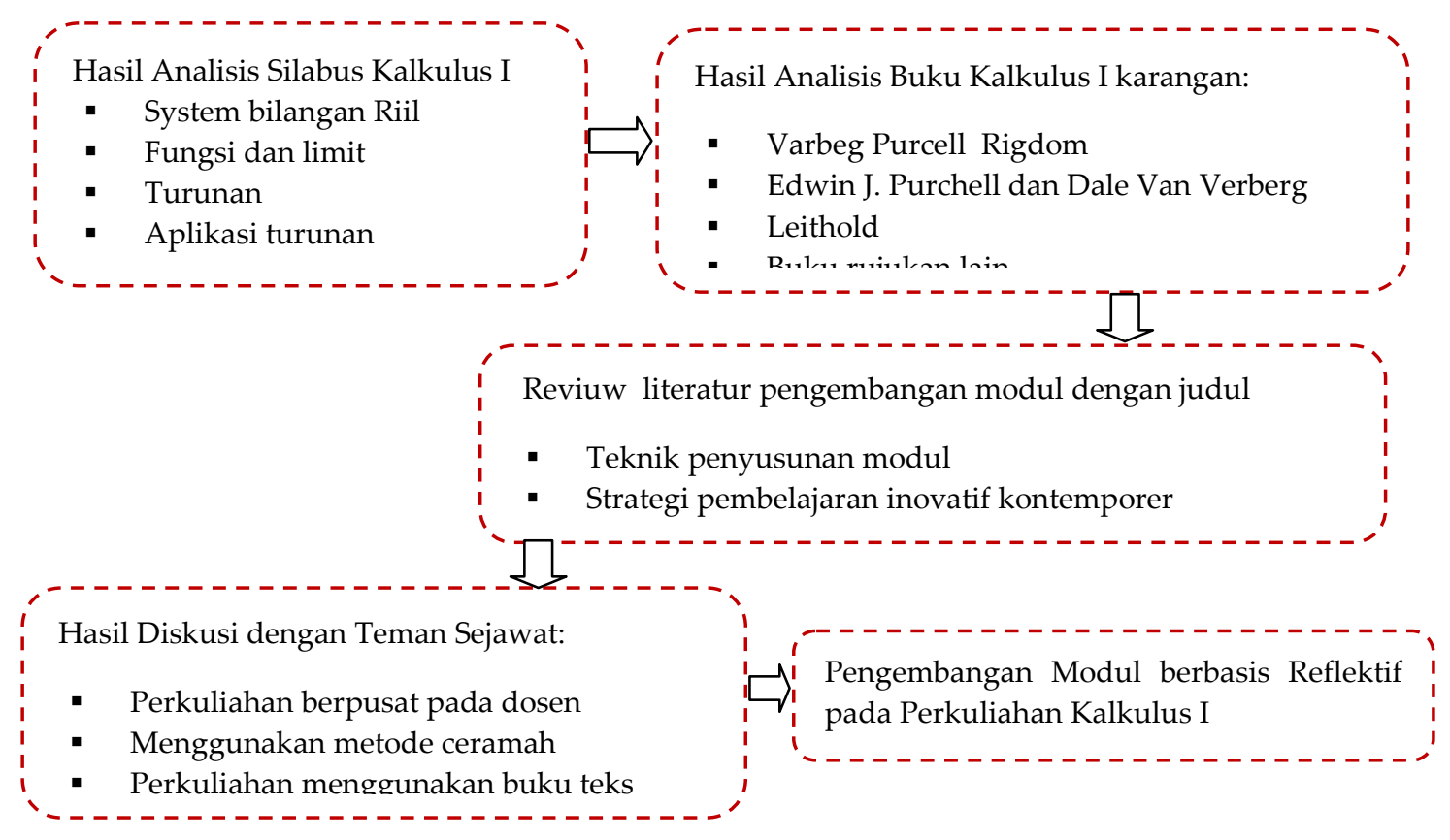

\section{Bagan 1. Diagram Hasil Tahap Define}

\section{Tahap Design}

Pada tahap design, dirancang modul berbasis reflektif dengan karakteristik sebagai berikut:

a. Setiap modul memiliki pendahuluan. Pada bagian pendahuluan memuat deskripsi singkat materii yang dibahas, relevansi dan tujuan instruksional. Deskripsi singkat berisi pernyataan tentang isi modul, dan relevansi yaitu pengaitan isi modul dengan modul lain dan, dan tujuan instruksional memuat kompetensi dasar dan indikator yang harus dimiliki mahasiswa setelah menggunakan modul tersebut. Salah satu halaman pendahuluan dari modul sebagai berikut:

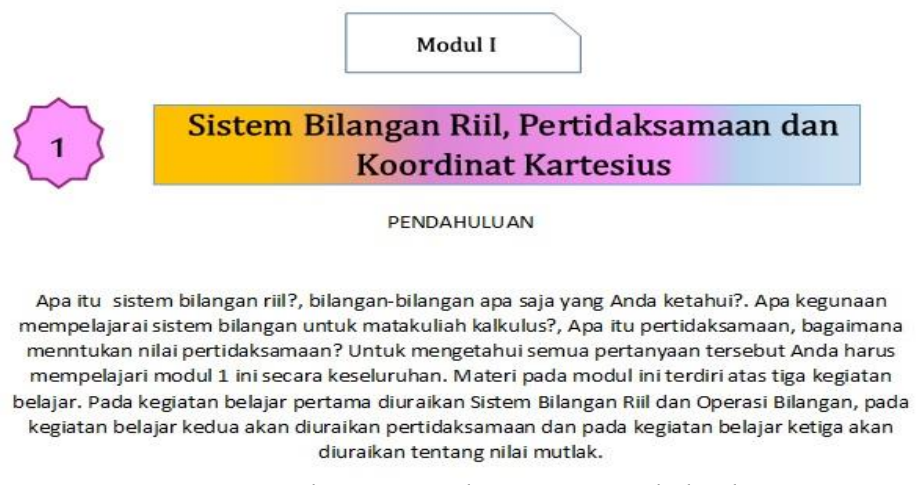

Gambar 1. Halaman Pendahuluan

b. Setiap kegiatan belajar berhubungan dengan pokok bahasan yang akan dibahas. Masalah yang diberikan berhubungan dengan pengalaman 
mahasiswa dalam keseharian. Berikut salah satu contoh berkaitan dengan konsep fungsi.

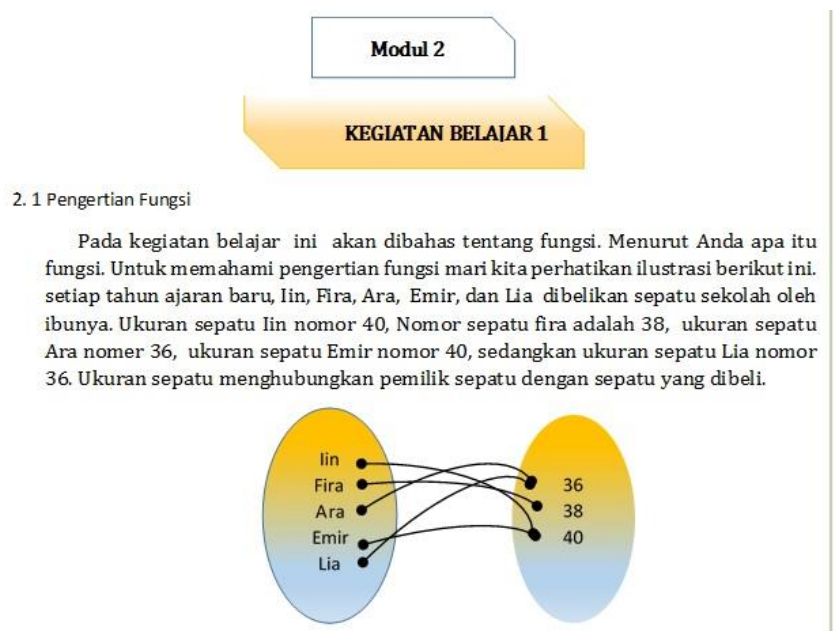

Gambar 2. Halaman Contoh

Modul ini dirancang berdasarkan urutan materi dan karakteristik produk/luaran yang diinginkan yakni modul berbasis reflektif yang terdiri dari empat pokok bahasan.

\section{Simpulan dan Saran}

Modul berbasis reflektif yang dikembangkan pada perkuliahan kalkulus I terdiri dari empat pokok bahasan yaitu: Modul 1 tentang Sistem bilangan Riil, Pertidaksamaan dan Koordinat Kartesius. Modul 2 tentang Fungsi dan Limit, Modul 3 tentang Fungsi, dan Modul ke 4 tentang Aplikasi fungsi.

Tahap perancangan dilakukan setelah melewati tahap define yakni, melakukan beberapa kegiatan, diawali dengan menganalisis silabus, buku teks, merevieu literature yang terkait serta melakukan wawancara dengan teman sejawat. Kegiatan yang akan dilanjutkan pada tahun kedua adalah: (1) memvalidasi modul berbasis reflektif; (2) melihat praktikalitas dan efektivitas modul berbasis reflektif, dilakukan melalui pengamatan aktivitas belajar dan hasil belajar mahasiswa; (3) Jika modul sudah dianggap valid, praktis, dan efektif maka akan disebarluaskan kepada mahasiswa di Prodi Pendidikan Matematika Universitas Khairun (desiminasi).

\section{Daftar Pustaka}

Hartono, W., \& Noto, M. S. 2017. Pengembangan modul berbasis penemuan terbimbing untuk meningkatkan kemampuan matematis pada perkuliahan kalkulus integral. JNPM (Jurnal Nasional Pendidikan Matematika), 1(2), 320-333. 
Noto, M. S. (2014). Perangkat Pembelajaran Matematika Berbasis SMART (Specific, Measurable, Achievable, Realistic, and Time-bound). Infinity Journal, 3(1), 18-32.

Purcell \& Varberg. 1992. Kalkulus \& Geometri Analitik, Jilid 1 Edisi ke lima, Jakarta: Penerbit Erlangga

Thiagarajan, S., Semmel, D. S \& Semmel, M. I. 1974. Instructional Development for Training Teachers of Exceptional Children: A Sourcebook

Suryadi, D. 2013. Didactical Design Research (DDR) to improve the teaching of mathematics. For East Journal of Mathemarical Education, 10 (1), pp. 91-107S

Sujadi, 2003. Metodologi Penelitian Pendidikan. Jakarta. Rineke Cipta

Trianto. 2007. Model Pembelajaran Terpadu dalam Teori dan Praktek. Jakarta: Prestasi Pustaka

Warsoma, D dan Wono, S. B. 2007. Kalkulus I . Diktat FMIPA ITB Bandung 